\title{
The French National otter Lutra lutra (Linnaeus, 1758) Action Plan
}

\author{
El Plan de Acción Nacional Frances de la nutria Lutra lutra (Linnaeus, 1758)
}

\section{Lutra lutra (Linnaeus, 1758) igarabaren Frantziako Ekintza Plan Nazionala}

\author{
Rachel Kuhn ${ }^{1 *}$ \\ 'Société Française pour l'Etude et la Protection des Mammifères (SFEPM), France. \\ * Corresponding author: rachelkuhn@yahoo.fr
}

\section{ABSTRACT}

A National Action Plan for the Eurasian otter Lutra lutra (Linnaeus, 1758) was written in 2009 by the French Mammal Society (SFEPM) and will be implemented from 2010 until 2015. This project is part of the action plan policy of the French Ministry of Ecology (MEEDDM). The first part of the plan is a status report on otter in France and the second part presents the conservation strategy for the next five years. The main issues of the plan are the strengthening of the stakeholder network and the development of cooperation to improve re-search and conservation, a better circulation of knowledge about otter biology and conserva-tion issues, the implementation of actions to reduce otter mortality, protect and restore otter habitat and increase prey availability and the improvement of cohabitation between otter and aquaculture.

KEYWORDS: anthropogenic mortality, communication, fish-farming, habitat conservation, public policy.

\section{RESUMEN}

El Plan de Acción Nacional para la nutria euroasiática Lutra lutra (Linnaeus, 1758) fue redac-tado en 2009 por la Sociedad de Mamíferos Francesa (SFEPM) y se está ejecutando durante el periodo 2010 - 2015. Este proyecto forma parte de la política de planes de acción del Ministe-rio Francés de Ecología (MEEDDM). La primera parte del plan es un informe de situación sobre la nutria en Francia y en la segunda parte se presenta la estrategia de conservación para los próximos cinco años. Los puntos principales del plan son el fortalecimiento de la red de colectivos involucrados y el desarrollo de la cooperación para mejorar la investigación y la conservación, una mejor difusión de los conocimientos acerca de los problemas de la biología y la conservación de la nutria, la implementación de acciones para reducir la mortalidad de la nutria, proteger y restaurar el hábitat de la nutria e incrementar la disponibilidad de presas y la mejora de la convivencia entre la nutria y la acuicultura.

PALABRAS CLAVE: mortalidad antropogénica, comunicación, piscicultura, conservación del hábitat, políticas públicas.

\section{LABURPENA}

Lutra lutra (Linnaeus, 1758) igaraba eurasiarrarentzako Ekintza Plan Nazionala 2009an idatzi zuen Ugaztunen Frantziako Sozietateak (SFEPM) eta 2010-2015 aldian ari dira gauzatzen. Proiektua Frantziako Ekologia Ministerioaren (MEEDDM) ekintza-planen politikaren baitan dago. Planaren lehen zatiak igarabak Frantzian bizi duen egoerari buruzko txostena jasotzen du. Bigarren zatian, aldiz, hurrengo bost urteotarako kontserbazio-estrategia dago jasota. Planaren puntu nagusiak honako hauek dira: gai horretan lanean ari diren kolektiboen sarea sendotzea eta lankidetza garatzea ikerketa eta kontserbazio hobea lortzeko, igarabaren biologiako eta kontserbazioko arazoei buruzko ezagutzak hobeto hedatzea, igarabaren heriotza-tasa gutxitzeko ekintzak ezartzea, igarabaren habitata babestea eta suspertzea, harrapakinen eskuragarritasuna handitzea eta igarabaren eta akuikulturaren arteko elkarbizitza hobetzea.

GAKO-HITZAK: Heriotza-tasa antropogenikoa, komunikazioa, arrain-hazkuntza, habitataren kontserbazioa, politika publikoak.

\section{INTRODUCTION}

In France, the Eurasian otter Lutra lutra (Linnaeus, 1758) used to be distributed over the whole country (except Corsica). The population declined sharply during the $20^{\text {th }}$ century be-cause of intensive trapping and destruction of the habitat. Protected since 1972, the otter is now recovering. However, this recovery is very slow because of the slow recruitment of the species and the persistence of threats like habitat destruction and road mortality. The otter is still absent from half of the country and is rare in many regions. The parts of the country where the otter is still missing are, in there majority, less suitable (higher human density, higher road traffic, lower ecological quality of the aquatic ecosystems).

The otter has become a flagship species and its popularity could be used to promote aquatic ecosystem conservation projects. In France, the number of local monitoring and conservation projects has increased in the last ten years (Jacques et al., 2005). However, there are discrepancies between regions and sometimes a lack of coordination and communication at a local and national level.

Also, not everybody is happy to see the otter coming back. Indeed fish-farmers are worried because of the damages that otters are sometimes causing on fish-farms (Leblanc, 2003).

For all those reasons, the Ministry of Ecology (MEEDDM) entrusted the French Mammal Society (SFEPM) with the writing of a National Action Plan for the Eurasian Otter (Kuhn, 2009).

The main issues of the action plan are:

- The strengthening of the stakeholder network and the development of cooperation to improve research and conservation, 
- A better circulation of knowledge about otter biology and conservation issues,

- The implementation of actions to reduce otter mortality, protect and restore otter habi-tat and increase prey availability,

- The improvement of cohabitation between otter and aquaculture.

The long term goal is the preservation of otter populations and re-colonization of the former home range, under the best possible coexisting conditions with human activities.

\section{OTTER DISTRIBUTION IN FRANCE}

In the eighties, the otter survived almost only in the Massif Central and in some parts of the Atlantic coast, which are regions with low human density and/or high food availability. Some small isolated populations also remained, particularly in the north of France. The two main populations started to expand in the nineties and are now joining each other (Rosoux \& De Bellefroid, 2006), whereas most of the small isolated populations disappeared (Fig. 1). An average re-colonization speed of $3.8 \mathrm{~km} / \mathrm{year}$, with maximum values of $10 \mathrm{~km} / \mathrm{year}$, was ob-served in the region Limousin, which is now almost entirely re-colonized (Dohogne \& Le-blanc, 2005, Leblanc et al., 2005).

The otter also became common in the neighbouring region Auvergne (Bouchardy, 2001). In the region Centre, the otter occurs in more than half of the department of Indre at the foot of the Massif Central (Dohogne \& Rosoux, 2006) and expands northwards and also along the river Loire. Actually, the population of the Massif Central expands in all directions. In Rhône-Alpes, the otter is now common in the department of Ardèche and also "reappeared" in the Alps (Bouché, 2008). In the regions Languedoc-Roussillon and Midi-Pyrénées, the otter oc-curs almost only in the southern part of the Massif Central and in the Pyrénées mountains (Cassoudebat et al., 2005 Defos Du Rau et al., 2005, Janssens, 2006, Janssens et al., 2008). The situation is quite unclear in ProvenceAlpes-Côte d'Azur where otter occurrence seems to be sporadic (Mathevet et al., 2005).

The otter occurs in many parts of the region Aquitaine but its distribution is apparently scat-tered. In the northeast of the region, the re-colonization of the department of Dordogne al-lowed the connection between the Atlantic and the Massif Central population. Northwards, the region Poitou-Charentes is becoming the main "meeting point"

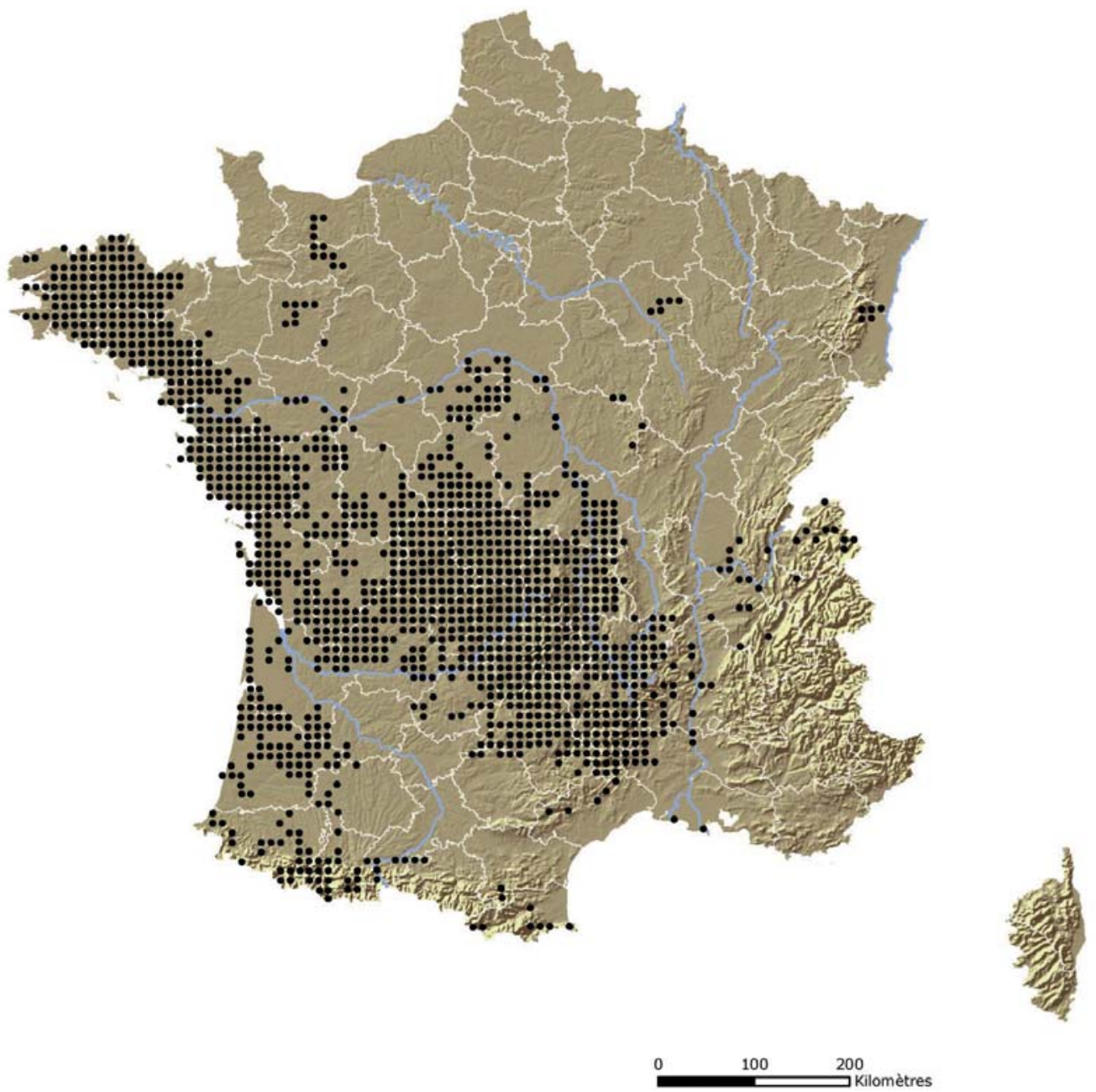

Fig. 1. - Otter distribution in France (Kuhn, 2009). (C) SFEPM/MNHN.

Fig. 1. - Otter distribution in France (Kuhn, 2009). (C) SFEPM/MNHN. 
between the otters de-scending from the mountain and those coming from the cost. Otters are abundant in the coastal part of the Pays-de-Loire but rare in the rest of the region (Texier \& Varenne, 2009). The otter has now re-colonized almost the whole Bretagne except the department of Ile-et-Vilaine (Simonnet \& Caroff, 2009). The species also occurs in some islands of the Atlantic coast (Kuhn, 2001, Mercier, 2003, Simonnet, 2006).

In Basse-Normandie, whereas the otter disappeared from the department of Manche, the small population of the department of Orne not only survived but expanded and began to re-colonize the neighbouring department of Calvados, following the course of the river Orne (Harivel, 2008). A small isolated population holds its ground in ChampagneArdenne. Rem-nants of a population are observed in Bourgogne but this region will probably soon be "sup-plied" with individuals coming from the south (Varanguin \& Sirugue, 2008). The otter offi-cially disappeared from the regions Haute-Normandie, Picardie, Nord-Pas-de-Calais, Ile-deFrance, Lorraine and Franche-Comté. In Alsace, where the species was also considered ex-tinct, 6 individuals were released between 1998 and 2001 (Mercier, 2004) but this small popu-lation probably will not survive.

\section{NEEDS OF THE SPECIES AND CONSERVATION STRATEGY}

Eurasian otters appear to be more flexible and more able to deal with human disturbances than thought to be. However, they need quiet places to rest and, most of all, to reproduce and raise their young. In places with important human activities, they particularly need good shelter. Food availability appears to be a very important limiting factor for otter populations. Popula-tion densities, and so chances to survive and to expand, increase with increasing prey availability. Eurasian otters have a low reproduction rate and a high natural mortality. So the addi-tion of anthropogenic mortality to those natural factors could rapidly be critical. Road mortal-ity appears to be a major threat.

The strategy presented in the action plan is divided into three parts: research, conservation and communication.

Considering the fact that the Eurasian otter is a quite well known species, the research part will be of minor importance, except for:

- Otter monitoring that should be developed using a standard method in order to update the distribution map regularly,

- The assessment of the potentiality for an area to be suitable for otters,

- The evaluation of the impact of otter predation on fish-farming and research of solu-tions.

It could be useful to improve the knowledge on sanitary risks (pathologies and impact of pol-lutants) and also on the effect of some factors (for example disturbance) but with a lower pri-ority because those aspects have been well studied in the past and several other projects are already planed or on their way in France and in other countries. The plan suggests to develop the use of genetic methods and also to study otters in coastal habitat in France, but this is op-tional.

The plan will concentrate on the "conservation" and "communication" part. Otter conserva-tion first involves a reduction of anthropogenic mortality and also the conservation and resto-ration of the habitat (particularly prey availability). To achieve this, a better consideration of otter in public policy is necessary. The improvement of ecological status of water bodies re-quired by the Water Framework Directive would benefit otters, in particularly if the species is taken into account while setting priorities. A better use of the Natura 2000 network for otter conservation would also be welcome; the list of Natura 2000 sites where the species occurs has to be updated and the otter must be considered while setting conservation strategies. The principal cause of death, and thus the one that has to be taken into account first, is road mor-tality. Nevertheless, other causes of mortality (trapping, shooting, fyke nets, dog bites...) should not be ignored. Ecological corridors could allow a faster re-colonization of some areas and, the most important, a reconnection of isolated populations.

Communication, exchange of information, cooperation (also international cooperation) should be developed. It is also necessary to deepen education of the public and all the stakeholders involved (decision makers, road constructors, dam constructors, fish-farmers, fishermen, an-glers, hunters, river managers, outdoor recreation organisers...).

A particular attention should be drawn to the conflict between otter and fish-farming. To han-dle this problem, it is recommended to compile knowledge on the subject, study otter behav-iour around fish-farming facilities, test systems to protect fish-farms, educate fish-farmers and offer them technical and financial help to protect their facilities from otter predation. A na-tional and international network of people working on this problem would be welcome.

\section{STRUCTURE OF THE ACTION PLAN}

The plan, written in 2009, presents the current situation of the Eurasian otter in France, recent projects, organisations working on otters, existing networks and the measures to take for the next 5 years. The plan proposes 31 actions (10 for the category "research", 10 for the category "conservation" and 11 for the category "communication"). Those actions are aimed to fulfil 5 specific objectives:

- Objective I: Improve the knowledge on the Eurasian otter, its distribution and the re-colonization possibilities and also develop efficient and standardized study methods,

- Objective II: Find solutions to coexisting problems between otter and human activities,

- Objective III: Improve the conservation status, in particular by means of measures to protect/restore the habitat and actions to reduce anthropogenic mortality,

- Objective IV: Inform, train and educate the decision makers, the wetlands and aquatic resources users and the public, 
- Objective V: Coordinate the actions and promote cooperation for otter research and conservation, through data centralisation and creation of a network of stakeholders and partners.

Each action is presented in a sheet including a degree of priority (from 1 to 3 ), the specific objective the action belongs to, the category (research, conservation or communication), the schedule, the context, the objective of the action, a description, the method, links with other actions of the plan, indicators to follow and evaluate the implementation, if possible a cost evaluation, potential partners (technical and financial) and eventually links with other action plans and references. For examples of actions see Table I.

\section{IMPLEMENTATION OF THE ACTION PLAN}

The implementation of the plan starts in autumn 2010. After having written the action plan, the SFEPM was chosen by the Ministry of Ecology (MEEDDM) to be the operator of the plan. Its mission will be: coordination of the implementation, running of a stakeholder net-work, communication, centralisation of information, writing of annual reports, fund-raising... A full time position has been opened to coordinate the implementation at a national level. The DREAL Limousin (regional agency of the MEEDDM) supervises the implementation at a local and at a national level on behalf of the MEEDDM who decided to decentralize the na-tional supervision of the action plans. The
Limousin, situated in the Massif Central, has been chosen because it is the region with the healthiest otter population in France (almost 100\% of the surface covered with signs) and because of its history in otter conservation (e.g. national otter conference in Limoges in 2004, unique experience in France of protecting fish-farms from predation by otters...).

Also, a National Steering Comity (Comité de Pilotage National) follows and evaluates the implementation and validates the decisions. This comity is made of representatives of the MEEDDM, Ministry of Agriculture, DREALs, MNHN (National Natural History Museum), ONCFS (French national agency for hunting and wildlife), ONEMA (French national agency for water and aquatic environments), ONF (National forest agency), nature reservations and parks, nature conservation organisations, scientists, road constructors, fishermen, anglers, fish-farmers, hunters, canoeing federation... The members of this comity meet between once and twice a year. The implementation gets financial support from the MEEDDM but additional funds have to be raised. Each DREAL is responsible of the implementation in its re-gion. Local organisations are invited to submit projects in accordance with the action plan. A couple of documents and communication tools (technical reports, flyers, exhibition...) on different topics (otter biology, habitat conservation, road traffic, fish-farming...) and for dif-ferent target audience (public, decision-makers, road constructors, fish-farmers, river manag-ers...) will be provided by the operator.

\begin{tabular}{|c|c|c|c|c|c|c|c|c|c|c|}
\hline \multirow{2}{*}{ 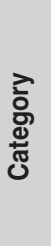 } & \multirow{2}{*}{ 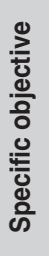 } & \multirow{2}{*}{ 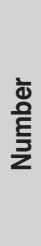 } & \multirow{2}{*}{ Title } & \multirow{2}{*}{$\begin{array}{l}\text { 츤 } \\
\text { 흔 }\end{array}$} & \multicolumn{6}{|c|}{ Schedule } \\
\hline & & & & & 웅 & 둥 & $\frac{N}{O}$ & ำ & ণ্ণ & ำ \\
\hline \multirow{5}{*}{ 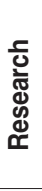 } & \multirow{4}{*}{ I } & 1 & Update the distribution map & 1 & $x$ & $x$ & $x$ & $x$ & $x$ & $x$ \\
\hline & & 4 & Develop the use of genetic methods & 3 & $x$ & $x$ & $x$ & $x$ & $x$ & $x$ \\
\hline & & 6 & Assess the potential for an area to be suitable for otters & 1 & $x$ & $x$ & & & & \\
\hline & & 7 & Study sanitary risks in otters & 2 & & & $x$ & $x$ & $x$ & $x$ \\
\hline & II & 10 & Test systems to protect fish-farms from otters & 1 & & $x$ & $x$ & $x$ & & \\
\hline \multirow{6}{*}{ 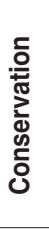 } & \multirow{6}{*}{ III } & 11 & Evaluate and improve the consideration of otters in public policy & 1 & $x$ & $x$ & $x$ & $x$ & $x$ & $x$ \\
\hline & & 14 & Create ecological corridors for otters & 1 & $x$ & $x$ & $x$ & $\mathrm{x}$ & $x$ & $x$ \\
\hline & & 15 & Edit a technical guide for aquatic ecosystems management & 1 & $\mathrm{x}$ & $x$ & $x$ & $x$ & $x$ & $\mathrm{x}$ \\
\hline & & 17 & Reduce road mortality & 1 & $\mathrm{x}$ & $x$ & $x$ & $x$ & $x$ & $x$ \\
\hline & & 19 & Avoid mortality due to trapping and hunting & 3 & & & $x$ & $x$ & $x$ & $\mathrm{x}$ \\
\hline & & 20 & Create otter havens & 2 & $x$ & $x$ & $x$ & $x$ & $x$ & $\mathrm{x}$ \\
\hline \multirow{6}{*}{ 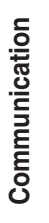 } & \multirow{5}{*}{ IV } & 21 & Develop communication tools and implement education programs & 2 & & $x$ & $x$ & $x$ & $x$ & $x$ \\
\hline & & 22 & Promote a good coexistence between otters and outdoor recreational activities & 3 & & & $x$ & $x$ & $x$ & $x$ \\
\hline & & 23 & Compile a report on "otter and fish-farming" & 1 & $x$ & $x$ & & & & \\
\hline & & 24 & Bring assistance to fish-farmers & 1 & $x$ & $x$ & $x$ & $x$ & $x$ & $x$ \\
\hline & & 26 & Create a system to collect otters found dead & 1 & $x$ & $x$ & $x$ & $x$ & $x$ & $x$ \\
\hline & V & 29 & Improve local and national coordination & 1 & $x$ & $x$ & $x$ & $x$ & $x$ & $x$ \\
\hline
\end{tabular}

Table 1. - Examples of actions from the French National Otter Action Plan.

Tabla 1. - Ejemplos de acciones del Plan de Acción Nacional Frances de la nutria 


\section{ACKNOWLEDGEMENTS}

Special recognition must be given to all the people who participated in the writing and editing of the action plan and, of course, to all those who will participate in its implementation. Many thanks to Hélène Jacques and François Moutou for proofreading this manuscript.

\section{BIBLIOGRAPHY}

Bouchardy C. 2001. La loutre d'Europe, histoire d'une sauvegarde. Catiche Produ-tions/Libris.

Bouche J. 2008. Loutre d'Europe Lutra lutra en Rhône-Alpes: point sur les observations en 2008 et contribution à l'actualisation de sa répartition en 2003-2007. Le Bièvre 22: 5-15

Cassoudebat L., Martin S., Molinier A., Tessier M., Bertrand A. 2005. Statut et conservation de la Loutre (Lutra lutra) en région Midi-Pyrénées. Arvicola 17: 9-16.

Defos du Rau P., Cano S., Doukhan G., Gomes R., Gonzalez E. Lacout P. 2005. Contribution à l'actualisation des connaissances sur la répartition de la Loutre d'Europe en région Midi-Pyrénées. La Conservation de la Loutre, actes du XXVIlème Colloque Francophone de Mammalogie de la SFEPM. Limoges: 63-70.

Dohogne R., Leblanc F. 2005. Actualisation de la répartition de la Loutre d'Europe (Lutra lutra) en Limousin. Rapport GMHL.

Dohogne R., Rosoux R. 2006. La Loutre (Lutra lutra) dans le département de l'Indre, évolu-tion du statut et répartition actuelle. Symbiose 16: 55-59.

Harivel R. 2008. Etude de la répartition de la Loutre d'Europe (Lutra lutra) sur l'Orne et ses affluents (14-61). Rapport CPIE des Collines Normandes. 16 pp (+ annexes).

Jacques H., Leblanc F., Moutou F. (Eds.) 2005. La Conservation de la Loutre. XXVIlème Colloque Francophone de Mammalogie de la SFEPM, Limoges, 2004. SFEPM/GMHL.

Janssens X. 2006. Monitoring and predicting elusive species colonisation: application to the otter in the Cévennes National Park (France). Thèse de Doctorat. Université catholique de Louvain. Louvain.

Janssens X., Fontaine M.C., Michaux J.R., Libois R., DE Kermabon J., Defourny P., Baret P.V. 2008. Genetic pattern of the recent recovery of European otters in southern France. ECOgraphy 31: 176-186.
Kuhn R.A. 2001. Etude de l'occupation et de l'utilisation des ressources trophiques de deux milieux côtiers de la façade atlantique par la Loutre d'Europe (Lutra lutra): la Baie de l'Aiguillon et l'lle d'Oléron (France). Mémoire de DES. Unité de Recherches Zoogéographi-ques, Université de Liège. Liège.

Kuhn R. 2009. Plan National d'Actions pour la Loutre d'Europe (Lutra lutra), 2010-2015. SFEPM/MEEDDM.

Leblanc F 2003. Protecting Fish Farms from Predation by the Eurasian Otter (Lutra lutra) in the Limousin region of Central France: First Results. IUCN Otter Specialist Group Bull. 20 45-48.

Leblanc F., Dohogne R., Guischer V., Thuaire N., Bellanger C., Constant J. 2005. Actualisa-tion de la répartition de la Loutre d'Europe en Limousin (2003/2004). La Conservation de la Loutre, actes du XXVIlème Colloque Francophone de Mammalogie de la SFEPM. Limoges: 9-28.

Mathevet R., Olivier A., Lucches J.L. 2005. La Loutre d'Europe dans le Grand Delta du Rhône: historique et perspectives. La Conservation de la Loutre, actes du XXVIIème Collo-que Francophone de Mammalogie de la SFEPM. Limoges: 47-54.

Mercier L. 2003. Régime alimentaire de la Loutre, Lutra lutra, sur l'île de Noirmoutier (Ven-dée). Le Naturaliste Vendéen 3 : 121-131.

Mercier L. 2004. Bilan de la réintroduction de la Loutre Lutra Iutra (Linné, 1758) en Alsace, France. Bull. Soc. Hist. Nat. Ethnol. Colmar 65: 117-134.

Rosoux R., De Bellefroid M.N. 2006. Le retour de la loutre en France. Symbiose 16: 60-62.

Simonnet F. 2006. Loutre d'Europe, la reconquête des rivières. Rev. Inf. eaux riviéres (supl. Spécial): 14-17.

Simonnet F., Caroff C. 2009. Contrat-Nature, Mammifères Semiaquatiques de Bretagne. Bilan 2005-2008. Rapport GMB

Texier A., Varenne F. 2009. La Loutre d'Europe. In: Mammifères, Amphibiens et Reptiles prioritaires en Pays de la Loire. B. Marchadour (Ed.): 50-51. Coordination régionale LPO Pays de la Loire/Conseil Régional des Pays de la Loire.

Varanguin N., Sirugue D. 2008. Vers une reconquête des rivières par la Loutre en Bourgogne. Rev. Sci. Bourgogne-Nature 8 : 205-227. 